\title{
HEAT TRANSFER CHARACTERISTICS OF PROPYLENE GLYCOL/WATER BASED MAGNESIUM OXIDE NANOFLUID FLOWING THROUGH STRAIGHT TUBES AND HELICAL COILS
}

\author{
P. Singh ${ }^{1 *}$, P. Sharma ${ }^{1}$, R. Gupta ${ }^{2}$, R.K. Wanchoo ${ }^{2}$
}

\begin{abstract}
Forced convective heat transfer studies on glycol based magnesium oxide nanofluids flowing through straight tubes and helical coils under laminar flow and constant wall temperature conditions have been conducted. Propylene glycol - water mixture (60:40 by wt.\%) was used as the base fluid and nanofluids with $\mathrm{MgO}$ nanoparticle volume concentration of $0.66 \%$ and $0.3 \%$ were used as the working fluids. Results showed that the convective heat transfer coefficient of nanofluid was higher than that of the base fluid for both straight tubes and helical coils. In straight tube, Nusselt number enhancement was $20 \%$ w.r.t. base fluid and it increased to $29 \%$ with increase in Peclet number from 44000 to 111400 for nanofluid having volume concentration of $0.66 \%$. While in helical coils, maximum enhancement in experimental Nusselt number was found to be $19.5 \%$ and $23 \%$ at volume concentration of $0.3 \%$ and $0.66 \%$ respectively for a curvature ratio of 0.0727 corresponding to a Dean number of 490.Two new correlations have been proposed to predict the heat transfer coefficient of magnesium oxide nanofluid flowing under laminar conditions through straight tube and helical coils.
\end{abstract}

Keywords: Magnesium Oxide, Straight Tube, Helical Coil, Convective Heat Transfer Coefficient, Constant Wall Temperature, Nusselt Number

\section{INTRODUCTION}

Power saving practices and concept of miniaturization of the heat transfer systems motivate many investigators to focus on enhancing the performance of these equipment. Changing the structural configuration of the heat exchanger and enhancing the thermo-physical properties of fluids flowing through these devices lead to enhancement of heat transfer efficiency [1]. Conventional heat transfer fluids with no phase change, like water, refrigerants, engine oil, glycols (ethylene glycol, EG) etc. exhibit poor heat transfer performance because of inherently low thermal conductivity. Introduction of metal and/or metal oxide solid particles into these heat transfer fluid enhances the thermal conductivity of the fluid medium [2]. The size of solid particles in these conventional fluids affects its thermal conductivity. The application of nanoparticles as additives to liquids is more noticeable and currently a large number of researchers are devoted to this subject. Conventional fluids with nanoparticles suspended in them are called nanofluids [3]. Nanofluids are engineered colloidal suspensions of nano particles (of size normally less than $100 \mathrm{~nm} \&$ in the conc. range of $0-5 \mathrm{vol} . \%$ ), which are more stable than micro particle colloids, with little particle settling, channel erosion and clogging [4]. Nanofluids have interesting properties such as large specific surface area, high thermal conductivity, less erosion and long term stability, thus making them potentially important as heat transfer fluids in heat exchangers, nuclear reactors, electronic cooling, fuel cells, pharmaceutical processes, food industry, etc. [5].

\section{Straight Circular Tubes}

Various researchers have investigated the flow characteristics and the heat transfer behavior of nanofluids with different types of nanoparticles and base fluids. Pak and Cho [6] studied experimentally the heat transfer performance of $\mathrm{Al}_{2} \mathrm{O}_{3}$ and $\mathrm{TiO}_{2}$ nanoparticles dispersed in water under turbulent flow conditions. The results showed that the Nusselt number of nanofluids increased with increasing volume concentration and Reynolds number. However, they reported that the heat transfer coefficient of nanofluid was $12 \%$ lower than that of base fluid, when compared under constant velocity conditions. New correlation was proposed for predicting heat transfer coefficient under turbulent conditions. Wen and Ding [7] reported the heat transfer studies on alumina water based nanofluid under laminar regime in a circular tube under constant heat flux conditions. They reported This paper was recommended for publication in revised form by Regional Editor Kwok-wing Chau

${ }^{1}$ Energy Research Centre, Panjab University, Chandigarh, 160014, INDIA

${ }^{2}$ Dr. SSB University Institute of Chemical Engineering and Technology, Panjab University, Chandigarh, 160014, INDIA

${ }^{*}$ E-mail address: parminder25@gmail.com

Manuscript Received 15 July 2016, Accepted 11 December 2016 
that at the entrance region the increase in heat transfer coefficient is significant and increases with increase in Reynolds number. Heyhat et al. [8] experimentally reported the heat transfer and pressure drop of $\mathrm{Al}_{2} \mathrm{O}_{3} / \mathrm{water}$ nanofluids flowing in a circular tube under fully developed laminar condition with constant wall temperature as a boundary condition. They concluded that the heat transfer coefficient for 2 vol. \% nanofluid increased by $32 \%$ approximately in comparison to base fluid and increases with increase in Reynolds number and particle concentration. Esfe et al. [9] experimentally studied the heat transfer behavior of $\mathrm{MgO}$ - water based nanofluids flowing through circular pipe for volume concentration less than $1 \%$ under turbulent conditions. Results showed an enhancement of $21.8 \%$ in Nusselt number for a $0.5 \%$ volume fraction at a Reynolds number of 6700 . Xie et al. [10] studied the convective heat transfer enhancement of various nanofluids as coolants in laminar flow inside a circular pipe under constant wall temperature conditions. Results showed that $\mathrm{Al}_{2} \mathrm{O}_{3}, \mathrm{ZnO}$ and $\mathrm{MgO}$ showed greater heat transfer enhancement. For $\mathrm{Re}=1000, \mathrm{MgO}$ having inherently non-corrosive character, showed a high heat transfer enhancement to the extent of $252 \%$. Table land 2 summarizes the work of various authors in the area of convective heat transfer of nanofluids.

\section{Helical Coils}

Kubair and Kuloor [24], and Schmidt proposed a correlation to calculate the convective heat transfer for helical coils under constant wall temperature boundary condition while Seban and McLaughlin [26] and Dravid et al. [27] presented the correlation for uniform heat flux boundary condition. Janssen and Hoogendoorn [28] and Manlapaz and Churchill [29] investigated the effect of torsion ratio for laminar flow in helical coils and observed that the torsion ratio can be neglected for lower coil pitch. Cioncolini and Santini [30] studied the effect of pressure drop for laminar, transition and turbulent flow regime in helical coils of different curvature ratios.

Jamshidi et al. [31] numerically investigated helical coils for thermal-hydraulic performance by using water and $\mathrm{Al}_{2} \mathrm{O}_{3}$ /water nanofluid. He suggested that the thermal performance of nanofluids in the helical coils was significantly affected by the coil diameter and coil pitch. Akhavan-Behabadi et al. [32] focused on using vertical helical coils instead of straight tubes because of high heat transfer rates. Also in comparison to base fluid flow, Nusselt number of nanofluids were much on a higher side. Hashemi et al. [33] carried out experimental studies on the heat transfer of oil based $\mathrm{CuO}$ nanofluid flowing inside a horizontal helical tube under constant heat flux

Table 1. Brief review of experimental work of various authors in the area of convective heat transfer of nanofluids

\begin{tabular}{|c|c|c|c|c|}
\hline Researcher & Nanofluids & $\begin{array}{l}\text { Boundary } \\
\text { conditions }\end{array}$ & Flow Regime & Results \\
\hline Xuan and Li [11] & $\mathrm{Cu} /$ water & Constant Heat Flux & Turbulent & $\begin{array}{l}\text { Conv. HTC increased with increase in } \\
\text { vol. fraction. For } \Phi=0.4 \text { wt. } \% \text {, for Pe } \\
\quad=420000, \mathrm{Nu} \text { increased by } 132 \% \text {. }\end{array}$ \\
\hline Li Qiang [12] & $\mathrm{Cu} /$ water & Constant Heat Flux & Laminar & $\begin{array}{c}\text { Nu number of nanofluid with } \Phi=2 \% \\
\text { was } 39 \% \text { higher than pure water. }\end{array}$ \\
\hline Lai et al. [13] & $\mathrm{Al}_{2} \mathrm{O}_{3} /$ water & Constant Heat Flux & Laminar & $\begin{array}{l}8 \% \text { enhancement in } \mathrm{Nu} \text { for } \Phi=1 \% \text { at } \\
\qquad \mathrm{Re}=270 .\end{array}$ \\
\hline Jung et al. [14] & $\mathrm{Al}_{2} \mathrm{O}_{3} /$ water & Constant Heat Flux & Laminar & $\begin{array}{l}\mathrm{Nu} \text { increased with increase in Re. } \\
\text { Convective HTC increased by } 32 \% \text { for } \\
\qquad \Phi=1.8 \% .\end{array}$ \\
\hline Heris et al. [15] & $\begin{array}{l}\mathrm{Al}_{2} \mathrm{O}_{3} / \text { water } \\
\mathrm{CuO} / \text { water }\end{array}$ & $\begin{array}{l}\text { Constant Wall } \\
\text { Temperature }\end{array}$ & Laminar & $\begin{array}{l}\text { HTC enhanced with increase in } \\
\text { volume fraction as well as Peclet no. } \\
\text { Also } \mathrm{Al}_{2} \mathrm{O}_{3} / \text { water showed more } \\
\text { enhancement. }\end{array}$ \\
\hline Anoop et al. [16] & $\mathrm{Al}_{2} \mathrm{O}_{3} /$ water & Constant Heat Flux & Laminar & $\begin{array}{l}\text { HTC showed higher enhancement in } \\
\text { the developing region and this } \\
\text { increased with increase in volume } \\
\text { concentration. }\end{array}$ \\
\hline Rea et al. [17] & $\begin{array}{c}\mathrm{Al}_{2} \mathrm{O}_{3} / \text { water } \\
\mathrm{ZrO}_{2} / \text { water }\end{array}$ & Constant Heat Flux & Laminar & $\begin{array}{l}\text { HTC in the fully developed region was } \\
\text { found to increase by } 27 \% \text { for } 6 \\
\text { vol. } \% \mathrm{Al}_{2} \mathrm{O}_{3} / \text { water nanofluid. }\end{array}$ \\
\hline
\end{tabular}

Table 2. Brief description of various correlations related to heat transfer of nanofluids 
Journal of Thermal Engineering, Research Article, Vol. 4, No. 1, pp. 1737-1755, January, 2018

\begin{tabular}{|c|c|}
\hline Reference & $\begin{array}{c}\text { Correlation } \\
\text { (Working conditions) }\end{array}$ \\
\hline Pak and Cho [6] & $\begin{array}{c}\mathrm{Nu}=0.021 \mathrm{Re}^{0.8} \mathrm{Pr}^{0.5} \\
\text { (Experimental study; Turbulent conditions; } \mathrm{Al}_{2} \mathrm{O}_{3} / \text { water; } \mathrm{TiO}_{2} / \text { water; Constant heat flux } \\
\text { conditions, } 0<\Phi<3.0 \text { vol. } \%, 6.5<\mathrm{Pr}<12.3 \text { ) }\end{array}$ \\
\hline Xuan and Li [18] & $\begin{array}{c}N u=0.0059\left(1+7.6286 \Phi^{0.6886} \mathrm{Pe}^{0.001}\right) \mathrm{Re}^{0.9238} \mathrm{Pr}^{0.4} \\
\text { (Experimental study; Turbulent flow; } \mathrm{Cu} / \text { water; Constant heat flux conditions, } \\
0<\Phi<2.0 \text { vol. \%) }\end{array}$ \\
\hline Li Qiang [12] & $\begin{array}{c}N u=0.4328\left(1+11.285 \Phi^{0.754} \mathrm{Pe}^{0.218}\right) \mathrm{Re}^{0.333} \mathrm{Pr}^{0.4} \\
\text { (Experimental study; Laminar conditions; } \mathrm{Cu} / \text { water; Constant heat flux conditions, } \\
0<\Phi<2.0 \text { vol. } \%, \mathrm{Re}<800)\end{array}$ \\
\hline Maiga et al. [19] & $\begin{array}{c}\qquad N u=0.28 \operatorname{Re}^{0.35} \mathrm{Pr}^{0.35} \text { for constant wall temperature } \\
N u=0.086 \operatorname{Re}^{0.55} \mathrm{Pr}^{0.5} \text { for constant wall heat flux } \\
\text { (Numerical study; Laminar conditions; } \mathrm{Al}_{2} \mathrm{O}_{3} / \text { water; } 0<\Phi<10 \text { vol. \%, } \mathrm{Re}<1000 \text { ) }\end{array}$ \\
\hline $\begin{array}{c}\text { Duangthongsuk and } \\
\text { Wongwises [20] }\end{array}$ & $\begin{array}{c}\qquad N u=0.074 \mathrm{Re}^{0.707} \mathrm{Pr}^{0.385} \Phi^{0.074} \\
\text { (Experimental study; Turbulent conditions; } \mathrm{TiO}_{2} / \text { water; Constant wall temperature, } \\
0.2<\Phi<2.0 \text { vol. \%) }\end{array}$ \\
\hline Vajjha et al. [21] & $\begin{array}{c}\mathrm{Nu}=0.065\left(\mathrm{Re}^{0.65}-60.22\right) \mathrm{Pr}^{0.542}\left(1+0.0169 \Phi^{0.15}\right) \\
\left(\text { Experimental study; Turbulent conditions; } \mathrm{Al}_{2} \mathrm{O}_{3} /(\mathrm{EG}+\text { water }) ; \mathrm{CuO} /(\mathrm{EG}+\text { water })\right. \\
\mathrm{SiO}_{2} /(\mathrm{EG}+\text { water }) ; \text { Constant heat flux, } 0<\Phi<6.0 \text { vol. \% for } \mathrm{CuO} /(\mathrm{EG}+\text { water }) \text { and } \\
\mathrm{SiO}_{2} /(\mathrm{EG}+\text { water }) ; 0<\Phi<10 \text { vol. \% for } \mathrm{Al}_{2} \mathrm{O}_{3} /(\mathrm{EG}+\text { water })\end{array}$ \\
\hline $\begin{array}{c}\text { Sajadi and Kazemi } \\
{[22]}\end{array}$ & $\begin{array}{c}\mathrm{Nu}=0.067 \mathrm{Re}^{0.71} \mathrm{Pr}^{0.35}+0.0005 \mathrm{Re} \\
\text { (Experimental study; Turbulent conditions; } \mathrm{TiO}_{2} / \text { water; Constant wall temperature, } \\
0.2<\Phi<0.25 \text { vol. \%) }\end{array}$ \\
\hline Asirvatham et al. [23] & $\begin{array}{c}N u=0.023 \operatorname{Re}^{0.8} \mathrm{Pr}^{0.3}+(0.617 \Phi-0.135) \operatorname{Re}^{(0.445 \Phi-0.37)} \mathrm{Pr}^{(1.08 \Phi-1.305)} \\
\text { (Experimental study; laminar, transition and turbulent conditions; silver/water; Constant wall } \\
\text { temperature, } 0.3<\Phi<0.9 \text { vol. \%) }\end{array}$ \\
\hline
\end{tabular}

conditions. They observed that the heat transfer is much more significant in helical coils as compared to straight tubes. Also, the tube curvature resulted in the pressure drop enhancement. Kumar et al. [34] investigated experimentally both the heat transfer and pressure drop of $\mathrm{Al}_{2} \mathrm{O}_{3} /$ water nanofluid in a shell and helically coil tube heat exchanger. Result showed an increase of 55\% for Nusselt number and $26 \%$ for friction factor for alumina water based nanofluid.

The data on the aqueous propylene glycol based magnesium oxide nanofluids flowing through straight tubes and helical coils is not available in the literature. Therefore, the present work is focused on the estimation of heat transfer coefficient of aqueous propylene glycol (60:40 by wt.\%) based $\mathrm{MgO}$ nanofluids flowing through straight tubes and helical coils under laminar flow and constant wall temperature conditions. Based on the present experimental data, two new correlations have been proposed for the prediction of Nusselt number for both straight tube and helical coils.

\section{MATERIALS AND METHODS}

$\mathrm{MgO}$ nanoparticles used in this experimental study were procured from Nanoshel. The XRD (X-ray diffraction) pattern of $\mathrm{MgO}$ nanoparticles is as shown in Figure1.The X-ray diffractogram shows the crystalline nature of the particles and confirms the presence of $\mathrm{MgO}$. The average particle size of $\mathrm{MgO}$ nanoparticles was calculated to be $22 \mathrm{~nm}$ using Debye - Scherrer formula [35].Thermo physical properties of $\mathrm{MgO}$ nanoparticles are shown in Table 3. Two step method was used for the preparation of $\mathrm{MgO}$ - aqueous glycol nanofluids. The required amount of nanoparticles was slowly added to the base fluid with the help of magnetic stirrer followed by homogenization and ultra - sonication. An ultrasonic probe (UP400S, Hielscher GmbH) was used for uniform dispersion of nanoparticles in an aqueous glycol mixture.

Two different volume concentrations $0.66 \%$ and $0.3 \%$ of $\mathrm{MgO}$ nanofluids were prepared. No surfactant was added. $\mathrm{pH}$ of the nanofluid was maintained at around 10.3 , to ensure that the nanoparticles were well dispersed. The nanofluids thus prepared were observed to be stable for at least one week. 


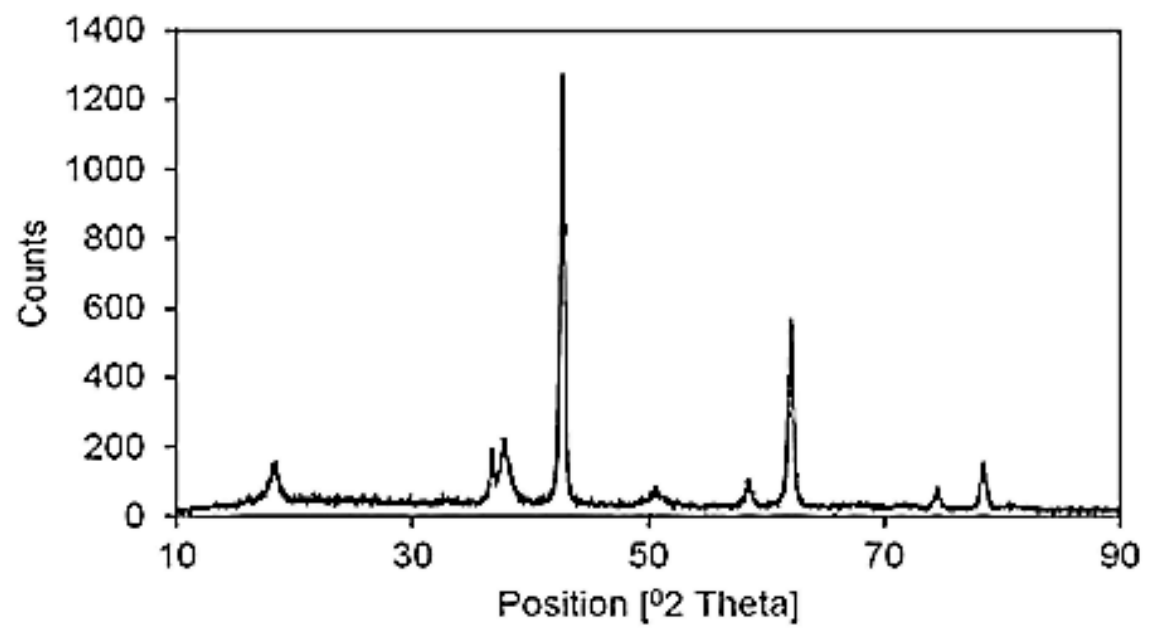

Figure 1. XRD analysis of MgO nanoparticles

Table 3. Thermo-physical properties of $\mathrm{MgO}$ nanoparticles ${ }^{36}$

\begin{tabular}{|c|c|c|c|}
\hline Nanoparticle & Density $(\boldsymbol{\rho})\left(\mathbf{k g} / \mathbf{m}^{\mathbf{3}}\right)$ & $\begin{array}{c}\text { Thermal Conductivity (k) } \\
(\mathbf{W} / \mathbf{m ~ K})\end{array}$ & $\begin{array}{c}\text { Specific Heat (Cp) } \\
(\mathbf{J} / \mathbf{k g ~ K})\end{array}$ \\
\hline MgO & 3560 & 45 & 955 \\
\hline
\end{tabular}

\section{EXPERIMENTAL INVESTIGATION}

\section{Estimation of nanofluid thermo-physical properties}

All physical properties of base fluid as well as that of nanofluids were measured using calibrated instruments. Density meter(Anton Paar, DMA48), Ubbelohde Viscometer and KD2 Pro thermal properties analyzer (Decagon devices, Inc., USA) were used to measure the density $(\rho)$,kinematic viscosity $(\mu)$ and thermal conductivity (k) respectively. Specific heat for base fluid were taken from ASHRAE [37].

Thermo - physical properties of base fluid $\left(20^{\circ} \mathrm{C}\right.$ to $\left.40{ }^{\circ} \mathrm{C}\right)$

Density

$$
\rho_{P G / W}=-0.0018 T^{2}-0.5318 T+1052\left(\operatorname{Tin}^{\circ} \mathrm{C}\right)
$$

Specific heat

$$
C_{p_{P G / W}}=4.4295 T+3251.8 \quad\left(\operatorname{T~in~}^{\circ} \mathrm{C}\right)
$$

Viscosity

$$
\mu_{P G / W}=21.67 e^{-0.04 T}
$$

Thermal conductivity

$$
k_{P G / W}=-1 \times 10^{-5} T^{2}+0.0014 T+0.2987\left(T \text { in }^{\circ} \mathrm{C}\right)
$$

Thermo - physical properties of nanofluid $\left(20^{\circ} \mathrm{C}\right.$ to $\left.35^{\circ} \mathrm{C}\right)$

Density of $\mathrm{MgO} / \mathrm{PG}-\mathrm{W}$ nanofluid with different volume concentration at different temperature were experimentally determined and were in good agreement with the theoretical equation given by Pak and Cho [6] :

$$
\rho_{n f}=\rho_{p} \Phi+\rho_{b f}(1-\Phi)
$$


where $\rho_{\mathrm{nf}}$ is the density of nanofluid, $\phi$ is the particle volume fraction, $\rho_{p}$ is the density of nanoparticles, $\rho_{b f}$ is the density of base fluid, i.e., $\rho_{P G / W}$.

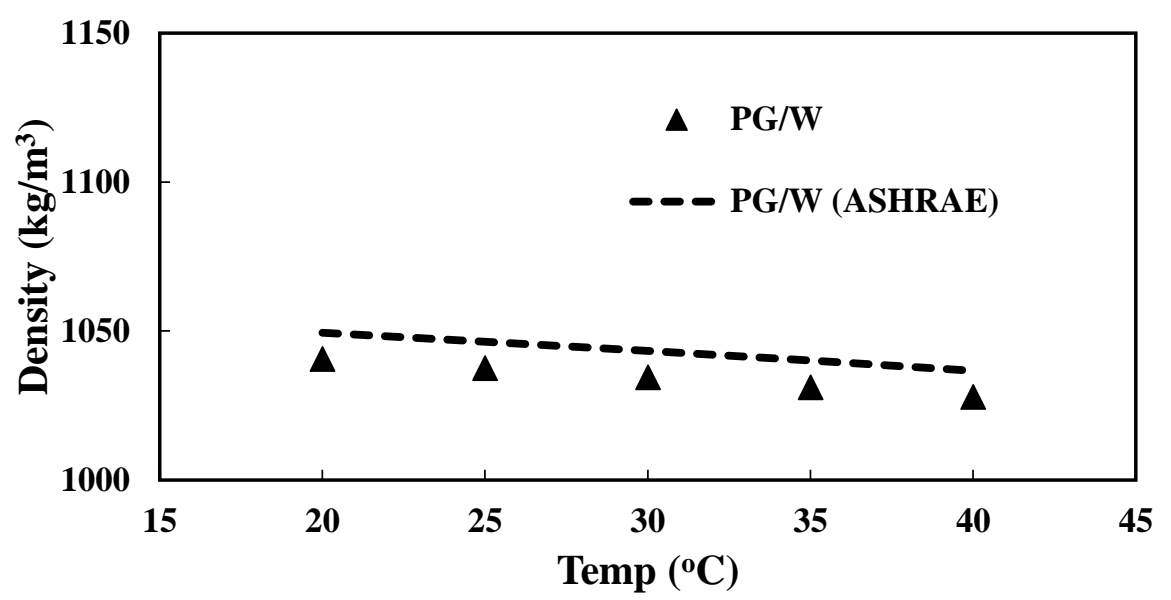

Figure 2. Density of propylene glycol - water mixture at different temperatures

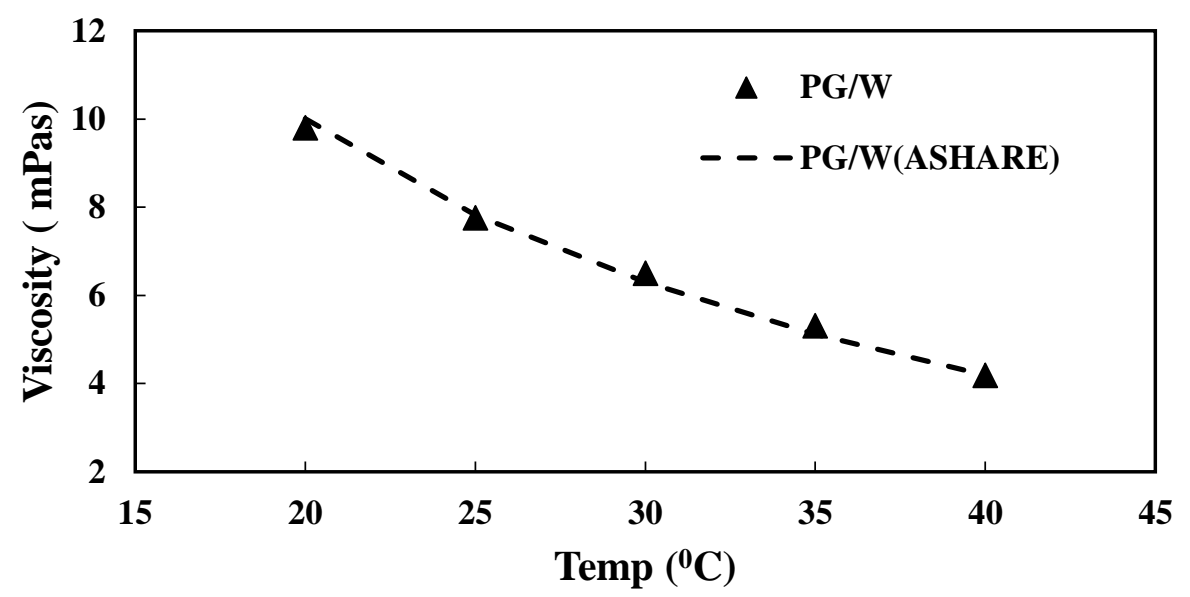

Figure 3. Viscosity of propylene glycol - water mixture at different temperatures

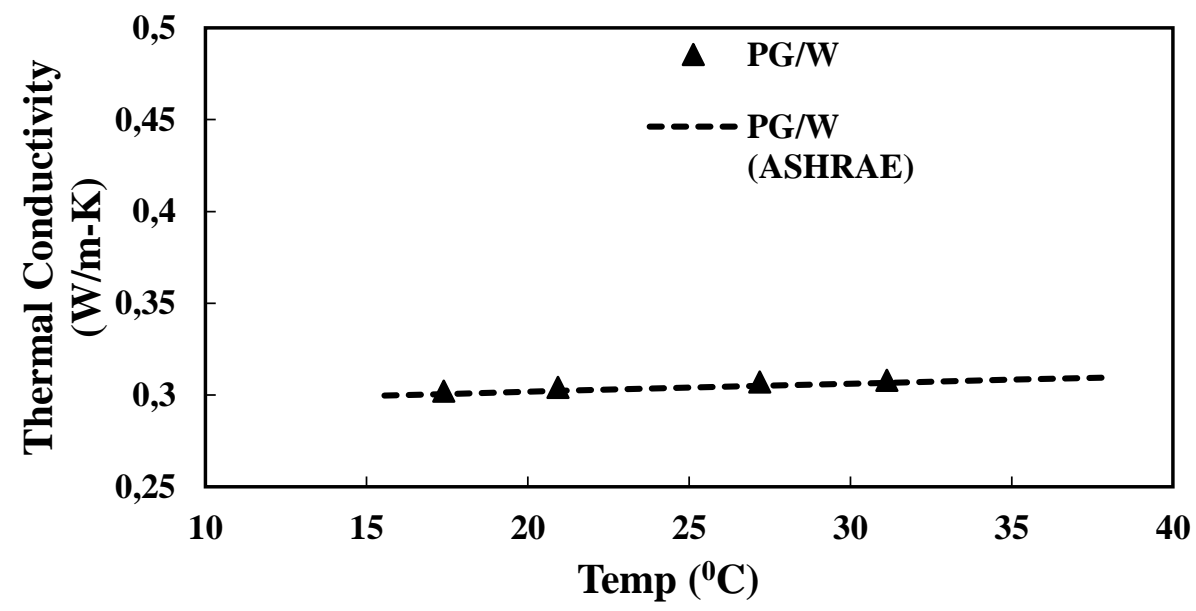

Figure 4. Thermal conductivity of propylene glycol - water mixture at different temperatures 
Figure 5 shows the comparison between experimental and predicted values using equation (5), for both the concentrations of nanofluid. As the particle volume concentration increased, the density of nanofluids also increased.

Specific heat

The specific heat of nanofluids was estimated by Pak and Cho [6] equation:

Viscosity

$$
C_{p_{n f}}=\frac{\Phi\left(\rho C_{p)_{p}}+(1-\Phi)\left(\rho C_{p)_{b f}}\right.\right.}{\Phi \rho_{p}+(1-\Phi) \rho_{b f}}
$$

The viscosity correlation for both the volume concentrations $(0.66 \% \& 0.3 \%)$ of $\mathrm{MgO} / \mathrm{PG}-\mathrm{W}$ nanofluid in the temperature range of $20{ }^{\circ} \mathrm{C}$ to $35{ }^{\circ} \mathrm{C}$ was given by Sharma et al. [38] :

Thermal Conductivity

$$
\begin{aligned}
& \mu_{0.66 \%}=1.536 e^{-4} \exp \left(\frac{3259}{T+273}\right) \\
& \mu_{0.30 \%}=7.940 e^{-5} \exp \left(\frac{3442}{T+273}\right)
\end{aligned}
$$

Thermal conductivity of 0.66 and 0.3 vol. \% MgO/PG-W nanofluid was measured using KD2 Pro thermal properties analyzer (Decagon Devices, Inc., USA). After sonicating the fluid for one hour, the thermal conductivity of each sample of different volume concentrations of the nanofluids was measured at a regular time interval. The average of concordant readings was taken as the final thermal conductivity value. Figure 6 shows the measured values of thermal conductivity at different temperatures for both the concentrations of $\mathrm{MgO} / \mathrm{PG}-\mathrm{W}$ nanofluid.

The observed data $\left(\frac{k_{n f}}{k_{b f}}=\mathrm{k}(\mathrm{T}),\right)$ was subjected to non-linear regression analysis resulting in the following correlation: $\frac{k_{n f}}{k_{b f}}=1+0.0838 \phi^{0.3372}$, where $k_{b f}$ was obtained from Equation (4).

\section{Experimental Setup Straight tube}

The test experimental setup for straight tube is shown in Figure 7. It consists of a tank with temperature controller, peristaltic pump, a calming chamber, a test section, a cooling unit, several temperature indicators and a flow measuring unit. The test section was a concentric chamber, consisting of inner copper tube and outer section of stainless steel. Two copper tubes with inner diameters of $12.96 \mathrm{~mm}$ and $15.9 \mathrm{~mm}$ each and wall thickness of $1.5 \mathrm{~mm}$ were used as the inner tube of a double pipe heat exchanger. Inner copper tube was surrounded by a stainless steel tube with inner diameter of $38 \mathrm{~mm}$. Effective length of each tube was $1.6 \mathrm{~m}$. Hot fluid was passed through the annular section to create a constant wall temperature boundary condition at the outside surface of the inner tube while the test nanofluid was passed through the inner copper tube. To control the temperature of the test fluid,

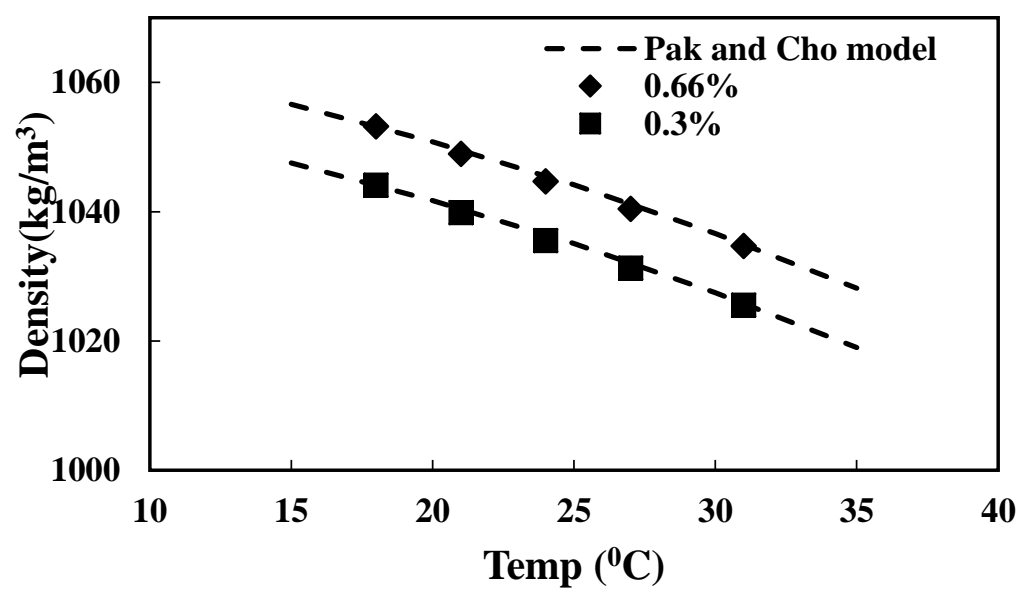

Figure 5. Density variation with temperature for both the concentrations of nanofluid. 


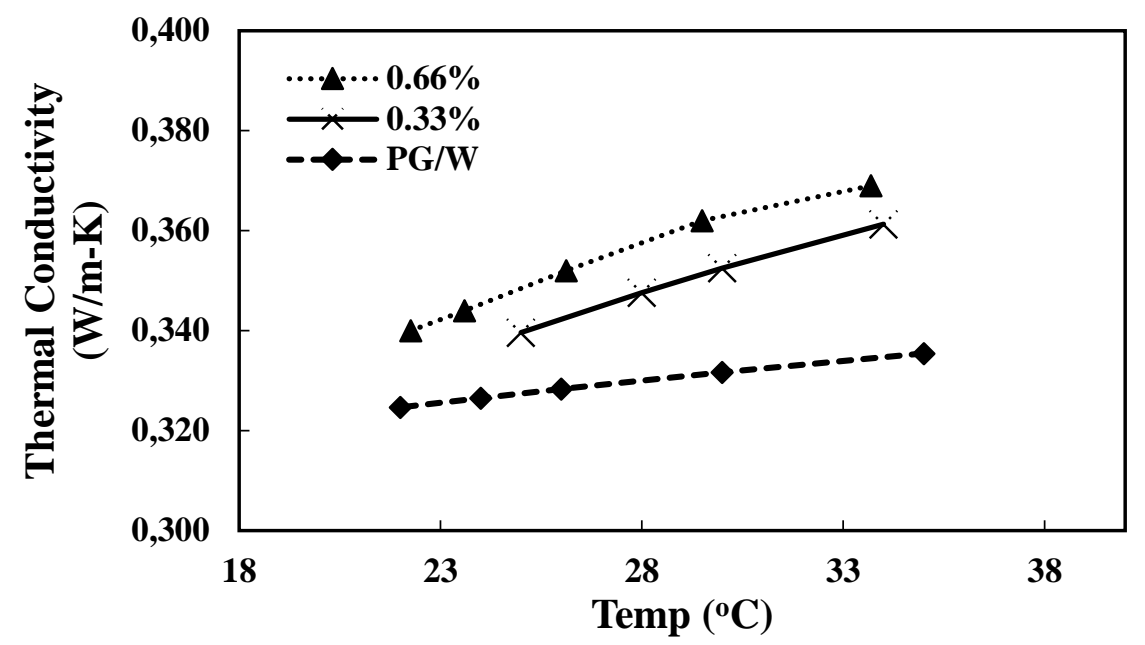

Figure 6. Thermal conductivity variation with temperature for base fluid and both the concentrations of nanofluid.

a cooling section was provided after the test section so as to keep the temperature constant at the inlet conditions. Five (K -type) thermocouples are welded on outer surface of copper tube at equal distances so as to record the temperature. Two ( $\mathrm{K}$ - type) thermocouples were inserted at inlet and outlet of the test section for measuring the bulk temperature of the test fluid. All thermocouples were first calibrated before carrying out the studies on the test fluids. Accuracy of these thermocouples was $\pm 0.1^{\circ} \mathrm{C}$. The volumetric flow rate was measured by noting down the time required to fill a certain volume. The test section was insulated by a thick glass wool followed by aluminum cladding in order to minimize heat loss to the surroundings. Negligible heat loss to the surroundings was assumed.

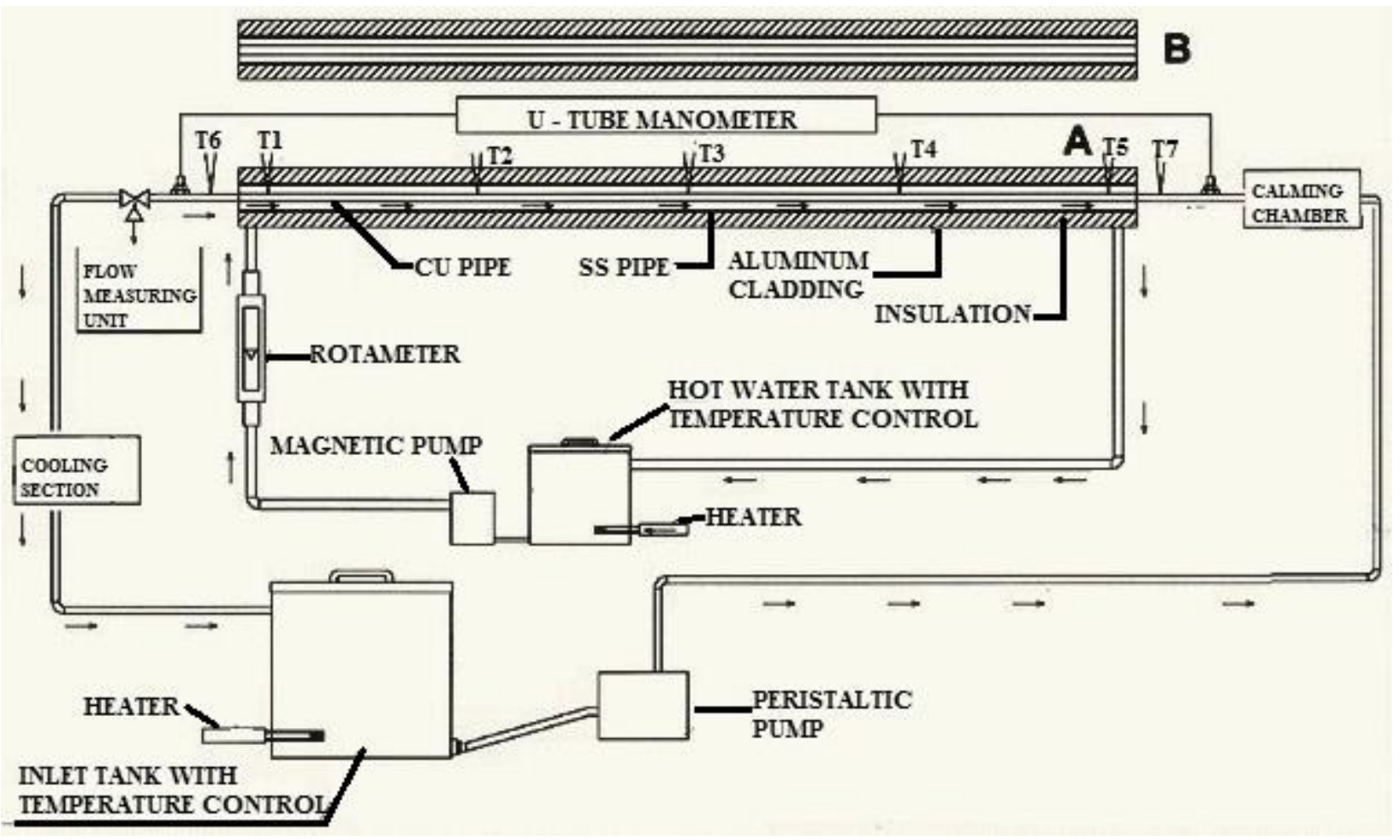

Figure 7. Schematic diagram of straight tube 
Table 4. Geometrical configurations of the helical coils

\begin{tabular}{|c|c|c|c|c|c|c|c|c|}
\hline \multirow[t]{2}{*}{ Helical coil } & \multirow{2}{*}{$\begin{array}{c}d_{i} \\
(\mathbf{m m})\end{array}$} & \multirow{2}{*}{$\begin{array}{c}d_{0} \\
(\mathrm{~mm})\end{array}$} & \multirow{2}{*}{$\begin{array}{c}D \\
(\mathrm{~mm})\end{array}$} & \multirow{2}{*}{$\begin{array}{c}\mathbf{L} \\
(\mathrm{m})\end{array}$} & \multirow[t]{2}{*}{$\mathbf{N}$} & \multirow{2}{*}{$\begin{array}{c}\text { Range of } \\
\text { application } \\
\text { C.R / P.R }\end{array}$} & \multicolumn{2}{|c|}{ Type of study } \\
\hline & & & & & & & $\begin{array}{l}\text { Flow } \\
\text { regime }\end{array}$ & $\begin{array}{l}\text { Boundary } \\
\text { Conditions }\end{array}$ \\
\hline Coil - I & 15.90 & 19.13 & 299.32 & 10.78 & 11 & $0.0533 / 1.51$ & Laminar & $\begin{array}{ll}\text { Constant } & \text { wall } \\
\text { temperature } & \end{array}$ \\
\hline Coil-II & 22.24 & 25.42 & 305.76 & 10.99 & 11 & $0.0727 / 1.49$ & Laminar & $\begin{array}{ll}\text { Constant } & \text { wall } \\
\text { temperature } & \end{array}$ \\
\hline Coil - III & 12.96 & 16.30 & 296.71 & 10.69 & 11 & $0.0437 / 2.57$ & Laminar & $\begin{array}{ll}\text { Constant } & \text { wall } \\
\text { temperature } & \end{array}$ \\
\hline
\end{tabular}

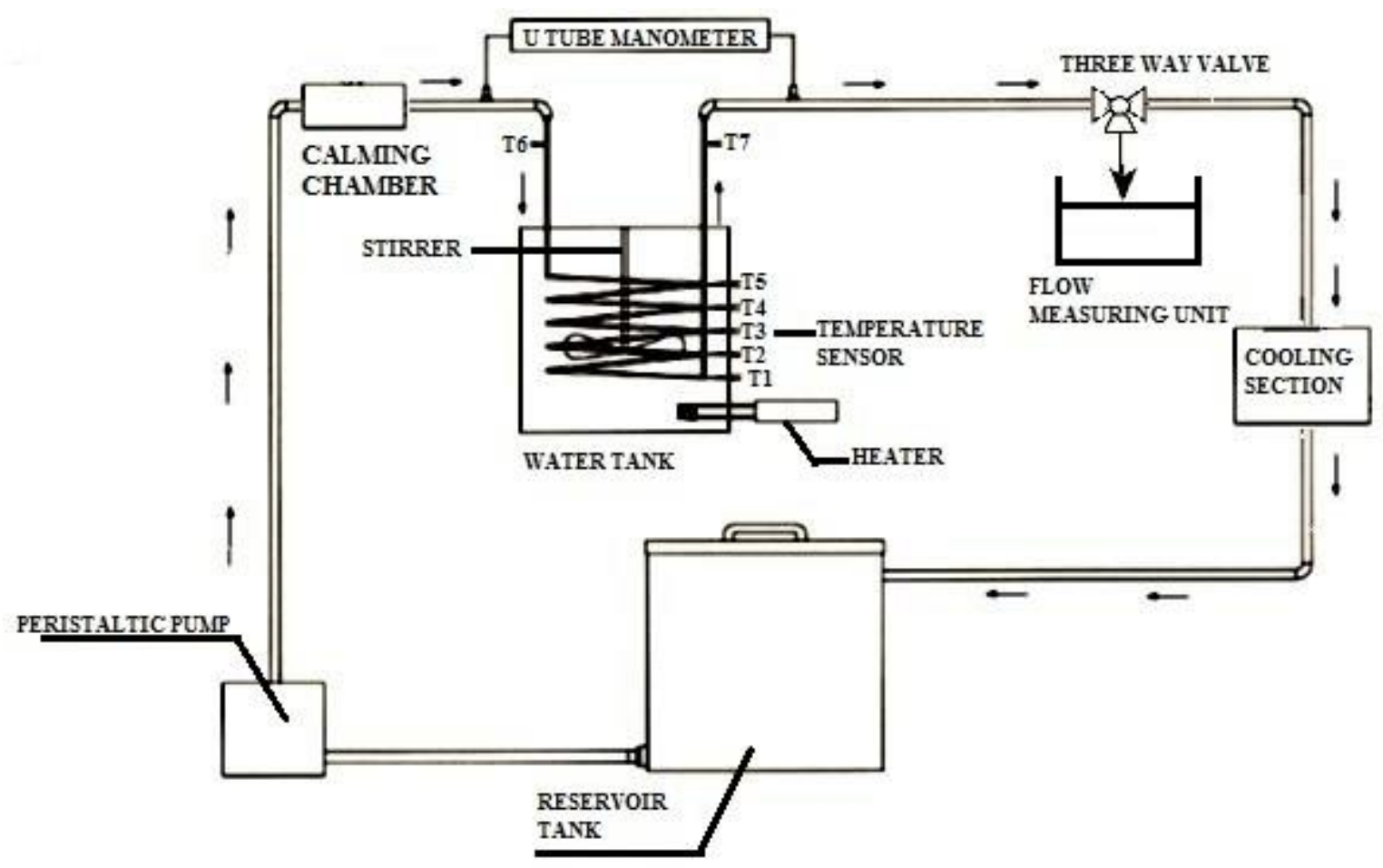

Figure 8. Schematic diagram of helical coil.

\section{Helical coils}

The schematic diagram of the experimental set up for the helical coils is shown in Figure 8. The physical dimension of helical coils used in the present investigation are given in Table 4. An insulated hot water vessel of size $410 \mathrm{~mm}$ x $410 \mathrm{~mm}$ x $650 \mathrm{~mm}$, with $10 \mathrm{~mm}$ thickness of mild steel was used to house the coils. Two electric heaters each of $1.5 \mathrm{~kW}$ were used in heating up of liquid surrounding the coils in the vessel. Temperature measurements are done in the same manner as in the case of straight tubes. Six thermocouples (K-type) are mounted at the same position on each alternate coil and two thermocouples (K-type) are inserted at the inlet and outlet of the coil.

\section{Data processing}

Heat transfer coefficient and the Nusselt number for fluid flowing under constant wall temperature conditions are calculated as follows: Rate of heat transfer from hot fluid to the cold fluid (nanofluid) is estimated based on the measurements of the inlet and outlet temperatures along with the volumetric flow rates of the hot fluid and the nanofluid. The following equations were used in calculations.

$$
\begin{gathered}
Q_{c}=m_{c} C_{c}\left(T_{c, o}-T_{c, i}\right) \\
Q_{h}=m_{h} C_{h}\left(T_{h, i}-T_{h, o}\right)
\end{gathered}
$$




$$
Q_{\text {average }}=\frac{Q_{c}+Q_{h}}{2}
$$

Overall and average convective heat transfer coefficients $\left(U\right.$ and $\left.h_{\text {exp }}\right)$ can be obtained as:

$$
\begin{gathered}
U=\frac{Q_{\text {average }}}{\left(A \Delta T_{L M T D}\right)} \\
(\Delta T)_{L M T D}=\frac{\left(T_{h, i}-T_{C, o}\right)-\left(T_{h, o}-T_{c, i}\right)}{\ln \left(\frac{T_{h, i}-T_{C, o}}{T_{h, o}-T_{C, i}}\right)} \\
h_{\text {exp }}=\frac{1}{\left(\frac{1}{U}-\frac{D_{o} \ln \frac{D_{o}}{D_{i}}}{2 k}\right)}\left(\frac{D_{o}}{D_{i}}\right) \\
N u_{\exp }=\frac{h_{\exp D}}{k}
\end{gathered}
$$

Conventional heat transfer correlations for straight tube and helical coils are as follows: For straight tube under laminar flow, $(\operatorname{Re}<2100)$ (Seider Tate correlation [39]) :

$$
N u_{S L}=1.86\left(\operatorname{Re} \cdot \operatorname{Pr} \cdot \frac{d}{L}\right)^{1 / 3}\left(\frac{\mu}{\mu_{w}}\right)^{0.14}
$$

where $\mu_{w}$ is fluid viscosity at wall temperature.

And for helical coil, (Manlapaz correlation [29]) :

$$
N u_{\text {coil }}=\left\{\left[3.657+\frac{4.343}{\left[1+\left(957 / P r \cdot H e^{2}\right)\right]^{2}}\right]^{3}+1.158\left[\frac{H e}{1+\frac{0.477}{P r}}\right]^{3 / 2}\right\}^{1 / 3}
$$

where Reynolds Number $R e=\frac{d_{i} v \rho}{\mu}$, Prandtl Number Pr $=\frac{c_{p} \mu}{k}$, Helical Number $H e=R e\left[\frac{d_{i} / d_{c}}{1+\left(\frac{p}{n d_{c}}\right)^{2}}\right]^{1 / 2}$

\section{RESULTS AND DISCUSSION}

\section{Straight Tubes}

The set-up was calibrated using distilled water. The experimental results were in close agreement with Seider-Tate correlation, equation (16), for laminar flow as shown in Figure 9. Figure 10 shows the variation of Nusselt number for the base fluid i.e. PG/water (60:40 by wt.\%) with Reynolds number.

$$
N u_{\text {modified }}=\frac{N u_{\exp }}{\left(\frac{d}{L}\right)^{1 / 3}\left(\frac{\mu_{n f}}{\mu_{\text {wnf }}}\right)^{0.14}}
$$

As shown in Figure 11 the modified Nusselt number $\left(N u_{\text {modified }}\right)$ of the nanofluids was higher than those of the base fluid (PG/water (60:40 by wt. \%)) and it increased with the increase in Peclet number as well as with the particle volume concentration. For $0.66 \%$ volume concentration, nanofluid showed an enhancement of $20 \%$ in Nusselt number and this enhancement increases to $29 \%$ with increase in Peclet number from 44000 to 111400 . Whereas for $0.3 \%$ volume concentration nanofluid shows an enhancement from $13 \%$ to $25 \%$ in the above said Peclet number range. One of the reasons for the better thermal performance of these nanofluids is due to combined 
effect of increase in the nanofluid thermal conductivity and the presence of Brownian motion of nanoparticles. Figures $12(\mathrm{a}, \mathrm{b}, \mathrm{c})$ show variation in $\Delta \mathrm{T}$, Rate of heat transfer, $\mathrm{Q}$ and the heat transfer coefficient, $\mathrm{h}$ respectively of the nanofluid flowing through the inner tube of the test section. Significant enhancement of $83.1 \%$ and $95.94 \%$ in rate of heat transfer, Q , and $30.24 \%$ and $70.84 \%$ in heat transfer coefficient, $\mathrm{h}$ in respect of the base fluid is observed with increase in concentration of $\mathrm{MgO}$ from $0.3 \%$ to $0.66 \%$ in the base fluid respectively at a Reynolds number of 1840 .

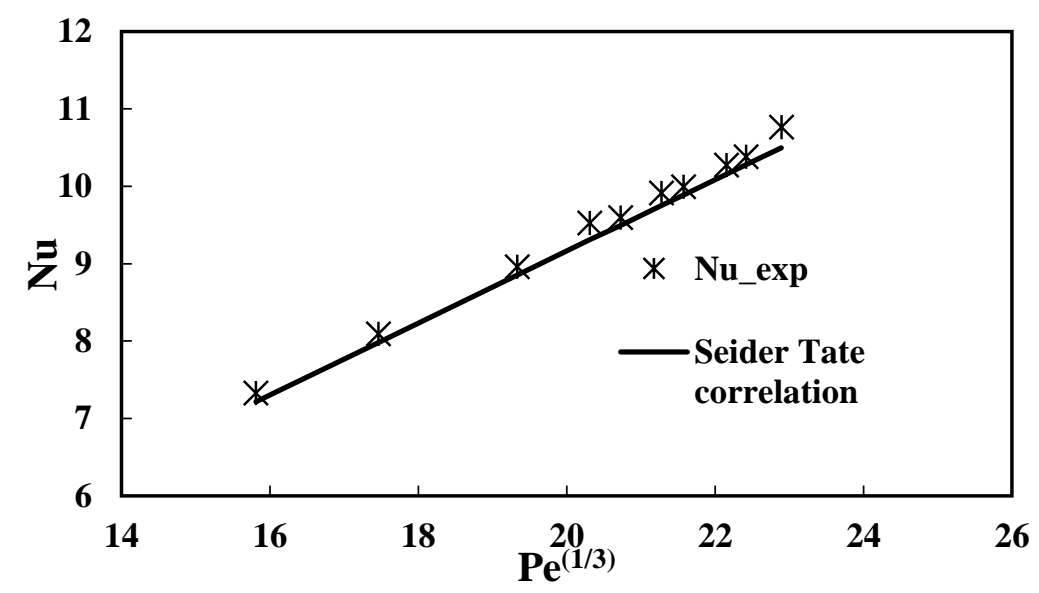

Figure 9. Nusselt number versus Peclet number for pure distilled water.

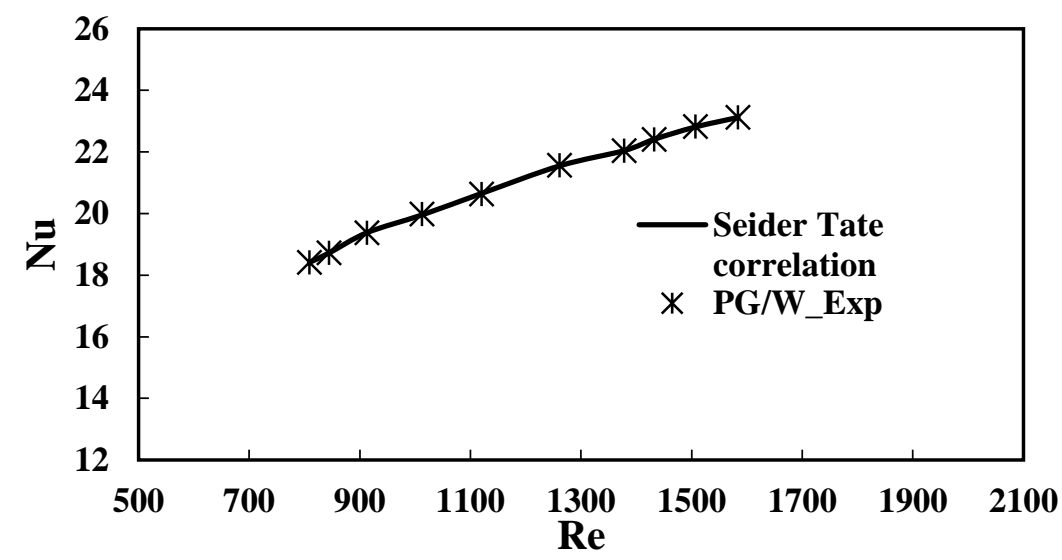

Figure 10. Nusselt number versus Reynolds number for PG/water base fluid.

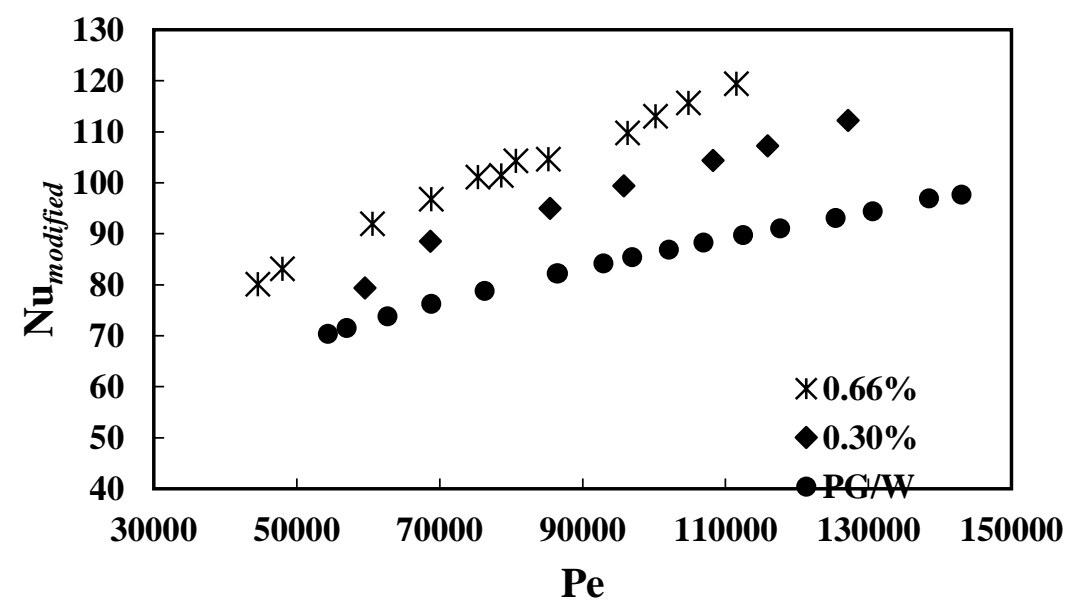

Figure 11. Experimental modified Nusselt number versus Peclet number for PG/water and MgO - PG/water nanofluid. 


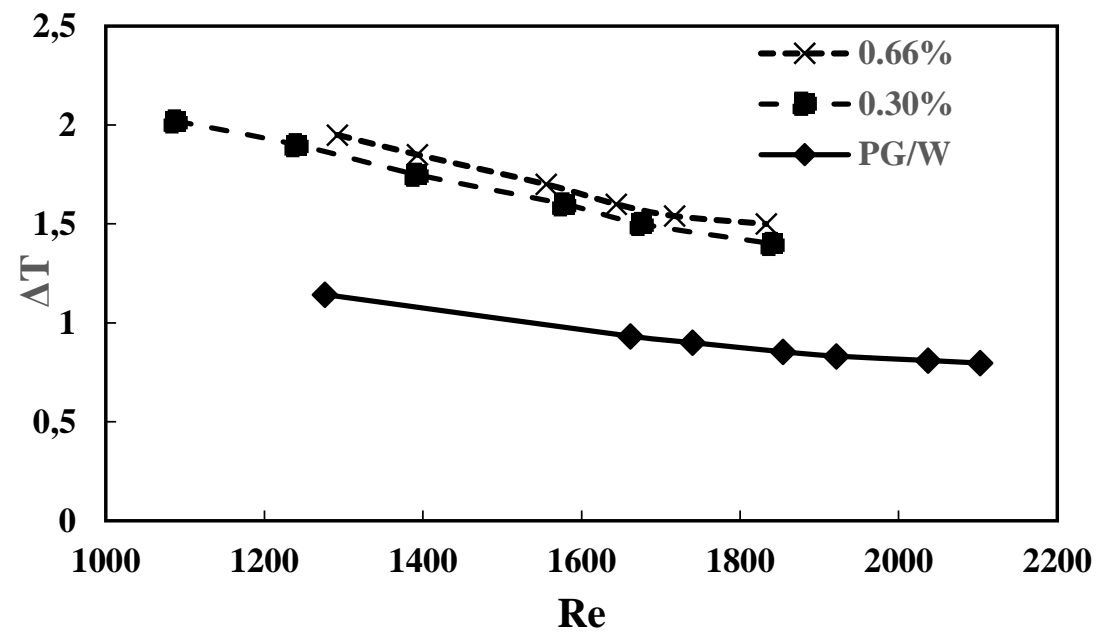

(a)

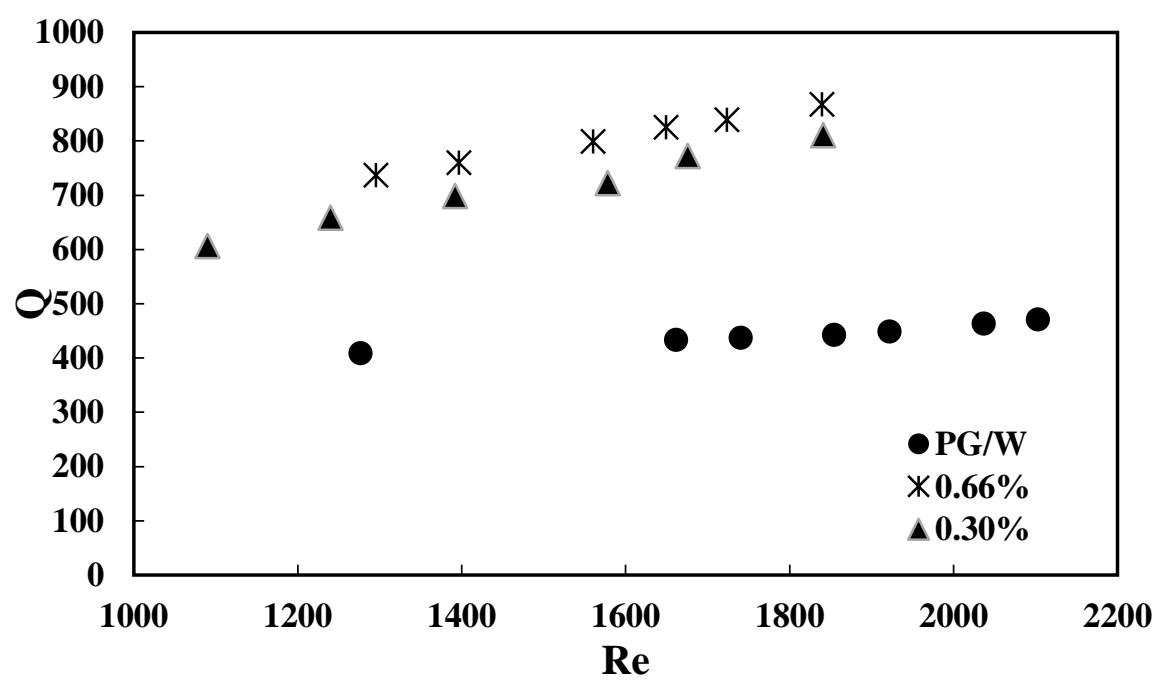

(b)

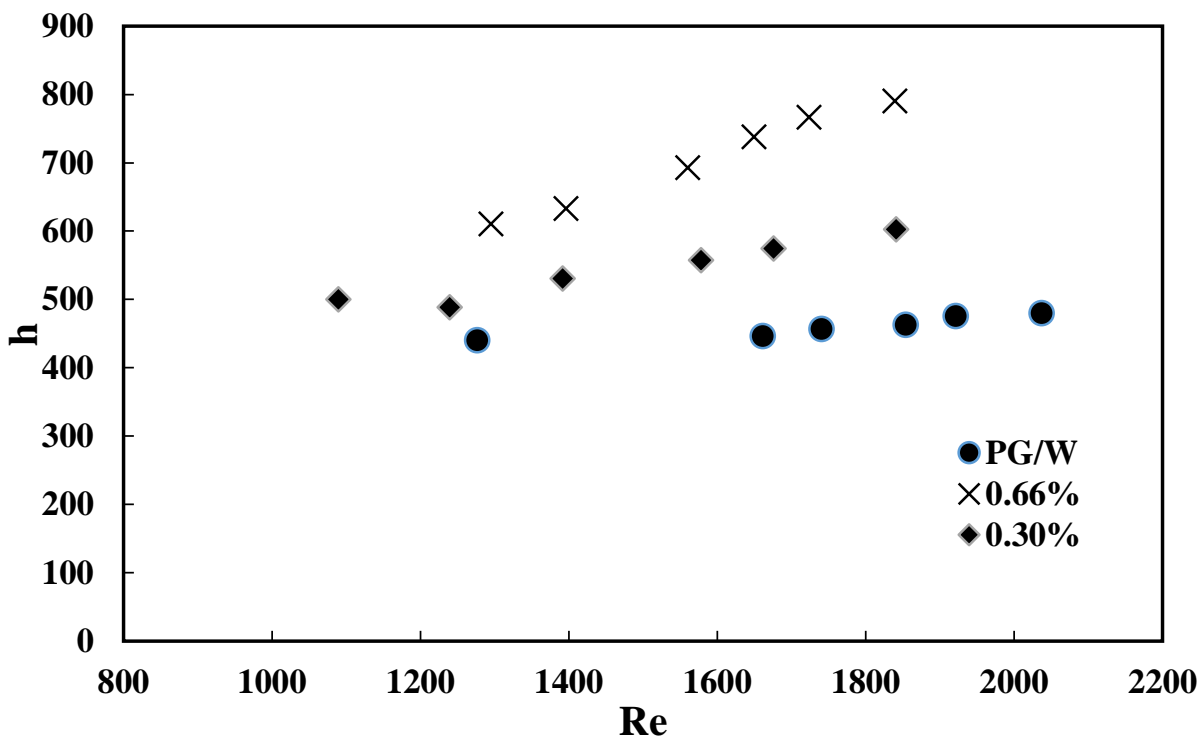

(c)

Figure 12. (a) Variation of $\Delta \mathrm{T}$ with Re for base fluid and nanofluid, (b). Variation of $\mathrm{Q}$ with $\mathrm{Re}$ for base fluid and nanofluid.(c) Variation of $\mathrm{h}$ with $\mathrm{Re}$ for base fluid and nanofluid. 


\section{Helical coils}

Figure 13 shows the variation of Nusselt number with Reynolds number for PG/W mixture for a constant pitch ratio and for curvature ratio of $0.0437,0.0531$ and 0.0727 . It is clearly evident that the Nusselt number increases with increase in Reynolds number and for a given Reynolds number, Nusselt number is higher for higher curvature ratio. Also the experimental results are in good agreement with the standard available correlation i.e. Manlapaz and Churchill correlation [29]. Further these results show better enhancement in helical coils in comparison to the flow through straight tube.

Figure 14 depicts the variation of Nusselt number of PG/water base fluid with respect to Dean Number, which takes into account both the Reynolds number and curvature effect. PG/water base fluid shows higher Nusselt number at higher Dean number. Figure 15 shows the effect of increasing volume concentration of $\mathrm{MgO}$ nanoparticles in PG/water mixture for coil - II of curvature ratio 0.0727. It is clear that the Nusselt number increased with the increase in particle volume concentration for a given Dean number. The maximum enhancement in experimental Nusselt number was found to be $19.5 \%$ and $23 \%$ at volume concentration of $0.3 \%$, and $0.66 \%$ respectively for a Dean number of 490 .

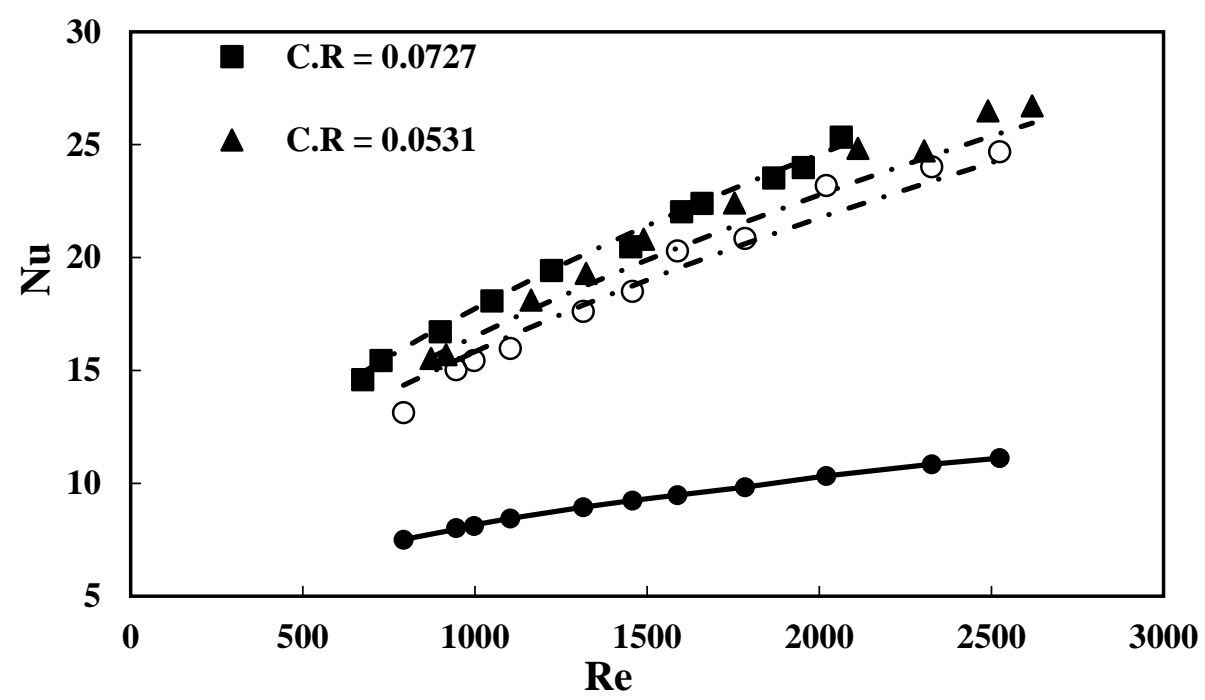

Figure 13. Experimental Nusselt number versus Reynolds number for PG/water mixture for different curvature ratios

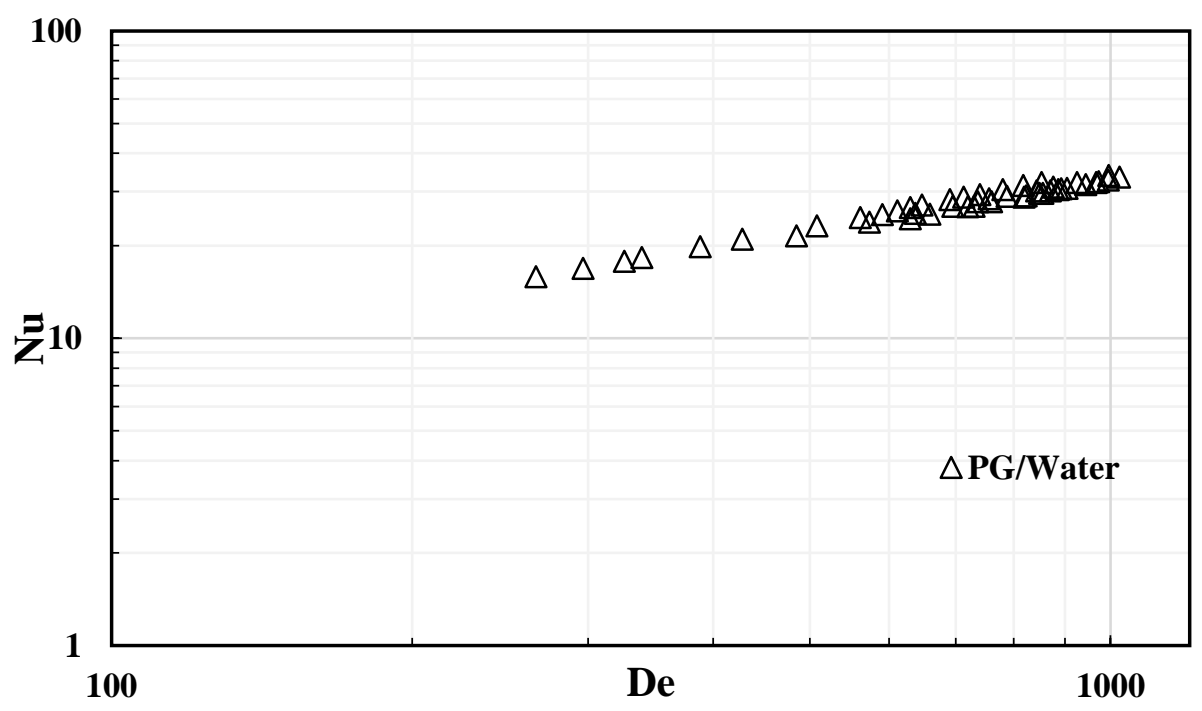

Figure 14. Experimental Nusselt number versus Dean number for PG/water base fluid 


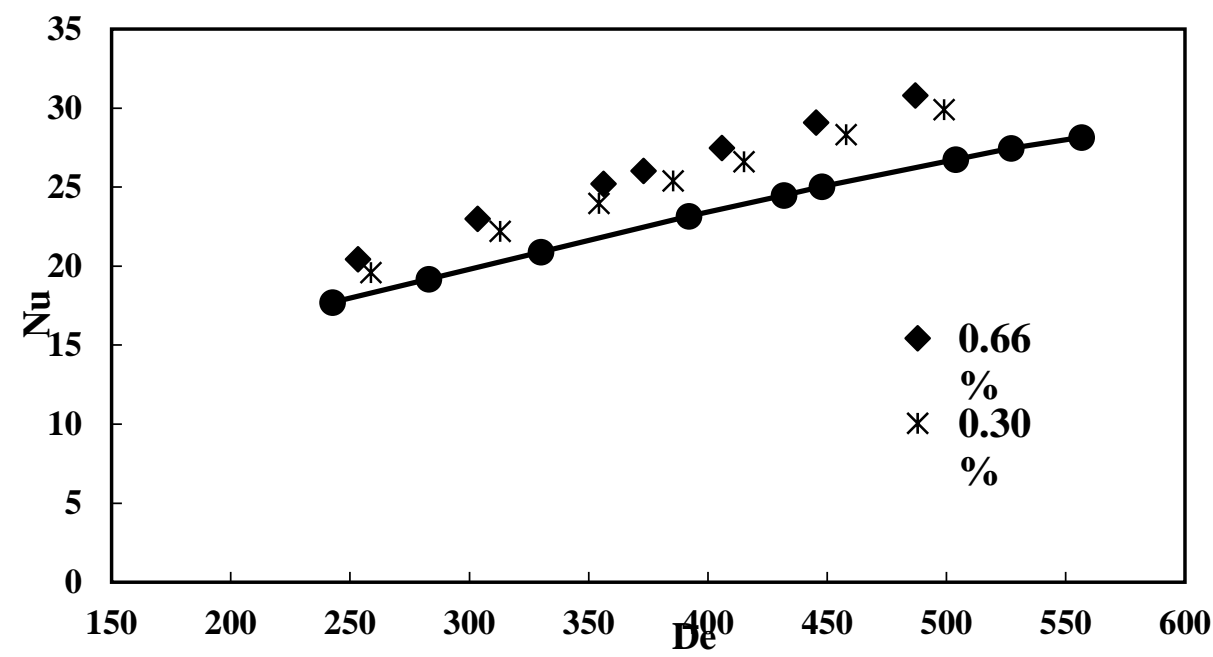

Figure 15. Experimental Nusselt number versus Dean number for $\mathrm{MgO}$ - PG/water nanofluid for Coil - II.

This is due to the presence of Brownian motion of the nanoparticles and higher enhancement in thermal conductivity of nanofluids. This increase in Nusselt number over Dean number is due to the formation of secondary flow. This flow provides proper mixing and stronger particle migration to enhance heat transfer coefficient. Similar results were obtained for other curvature ratios as well.

\section{Data Analysis}

\section{Base fluid}

In Helical Coil: Figure 16 shows the variation of Nusselt number ratio of PG/water base fluid w.r.t Dean number. Nusselt number ratio is defined as the ratio of Nusselt number of coil to that of Nusselt number of straight tube. It was observed that the variation of Nusselt number ratio with Dean number can be expressed in the form as

$$
N u_{\text {Ratio }}=\frac{N u_{\text {Coil }}}{N u_{S T}}=1+a D e^{b}
$$

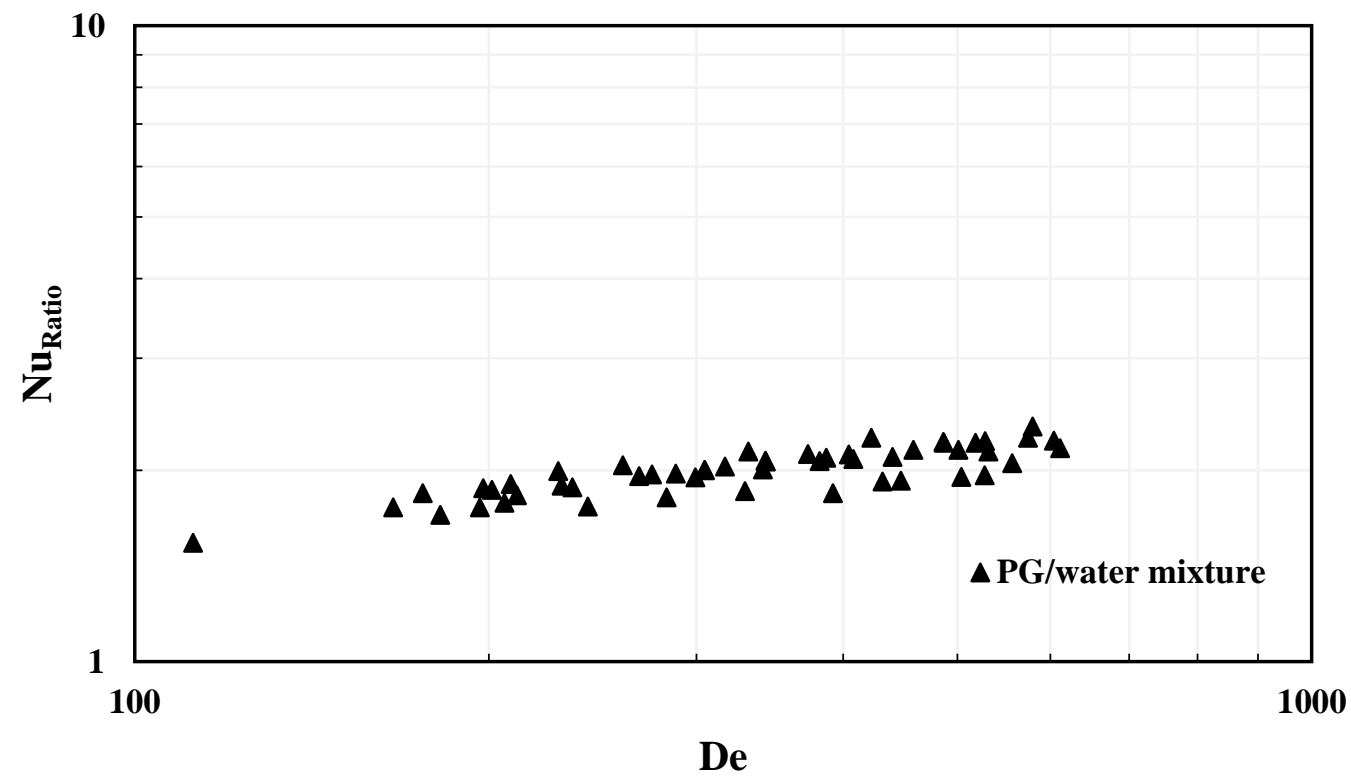

Figure 16. Nusselt number Ratio $\left(\mathrm{Nu}_{\mathrm{Coi}} / \mathrm{Nu}_{\mathrm{ST}}\right)$ vs Dean number for $\mathrm{PG} /$ water base fluid. 
Using non - linear regression techniques, the correlation constants of equation 19 were obtained as: $a=$ 0.060 and $b=0.484$.

Different types of statistical parameters like Mean Relative Quadratic Error (MRQE) and Average Relative Error (ARE) were also estimated.

MRQE. (Mean Relative Quadratic Error) $=\sqrt{\frac{\left(\frac{\text { experimental-theroetical }}{\text { experimental }}\right)^{2}}{N-1}}$

and ARE (Average Relative Error) $=\frac{100}{N}\left|\frac{\text { experimental }- \text { theroetical }}{\text { experimental }}\right|$ where $\mathrm{N}$ is the number of data points.

Table 5. Statistical errors for straight tube

\begin{tabular}{|c|c|c|}
\hline Correlation & MRQE & ARE \% \\
\hline New correlation (equation (20)) & 0.002 & 0.147 \\
\hline Sharma and L. Syam [40] & 0.587 & 56.040 \\
\hline
\end{tabular}

Table 6 shows the values of different statistical errors calculated between the new proposed correlation i.e. equation 19 , and the available correlations in the literature.

Table 6. Statistical errors for base fluid in helical coils

\begin{tabular}{|c|c|c|}
\hline Correlations & MRQE & ARE \% \\
\hline Proposed correlation (equation (19)) & 0.016 & 0.997 \\
\hline Dravid et al. [27] & 0.311 & 30.297 \\
\hline Janssen [28] & 0.288 & 24.251 \\
\hline Manlapaz [29] & 0.054 & 4.153 \\
\hline
\end{tabular}

Figure 17 shows the parity plot between the experimental Nusselt number and the predicted Nusselt number for new proposed correlation and Manlapaz and Churchill correlation [29]. It is clearly observed that Manlapaz and Churchill correlation [29] predicted the experimental data within $\pm 15 \%$ whereas the new proposed correlation predicted the Nusselt number reasonably well within $\pm 4 \%$.

\section{Nanofluid}

Based on the experimental data of both the volume concentrations of $\mathrm{MgO}$ nanofluid, new correlations for straight tube and for helical coils have been proposed.

For straight tube: Proposed model is

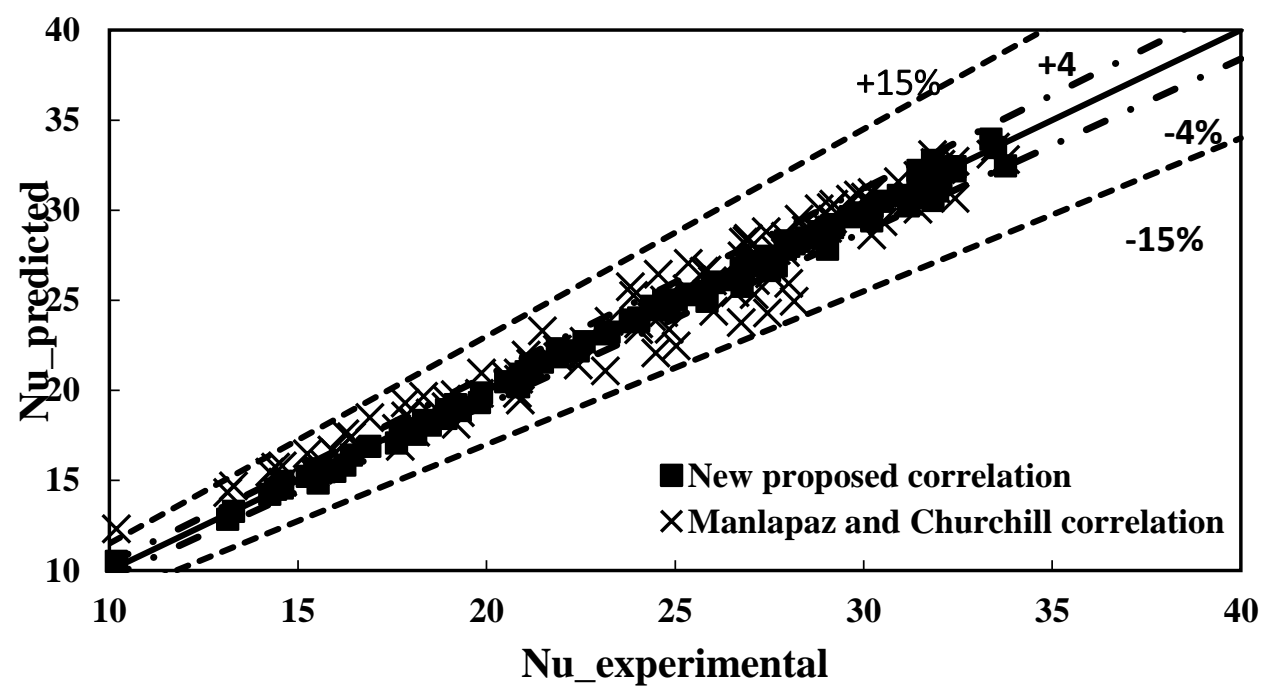

Figure 17. Mean deviation between predicted and experimental Nusselt number for proposed correlation and Manlapaz correlation ${ }^{29}$. 


$$
N u_{S T \_ \text {modified }}=\frac{N u_{\text {exp }}}{\left(\frac{d}{L}\right)^{1 / 3}\left(\frac{\mu_{n f}}{\mu_{w n f}}\right)^{0.14}}=1.86\left(P e^{1 / 3}\right)\left[1+m\left(\frac{\Phi}{1-\Phi}\right)^{n}\right]
$$

Using non - linear regression techniques, $m \& n$ were obtained as $m=4.900$ and $n=0.576$. Statistical parameters like MRQE and ARE were also estimated.

Various available correlations in literature were also compared with the new proposed correlation. Table 6 shows the comparison based on statistical errors. Also as seen in Figure 18, the proposed correlation predicted the experimental data well within $\pm 5 \%$.

For helical coils: Proposed correlation for nanofluids flowing through helical coil is represented in the similar way as represented for base fluids i.e.

$$
N u_{\text {Ratio }}=\frac{N u_{\text {Coil }}}{N u_{S T_{-} \text {modified }}}=\left(1+A D e^{B}\right)
$$

where $N u_{S T \_m o d i f i e d}$ is given in equation 20. Using non - linear regression techniques, constants were calculated as $\mathrm{A}=0.052 \& \mathrm{~B}=0.515$. Different statistical errors were also calculated. The proposed correlation gave MRQE $=0.029$ and $\mathrm{ARE}=2.230 \%$ for the present experimental data. Figure 19 shows that the proposed correlation predicted the experimental data well within $\pm 5 \%$.

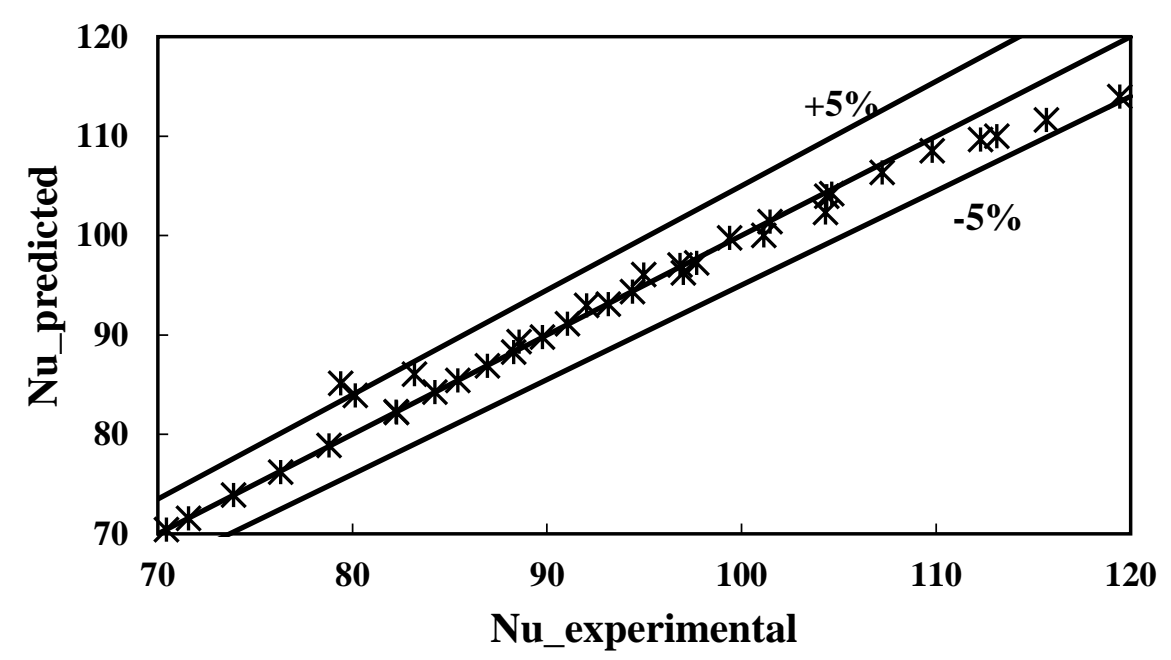

Figure 18. Parity plot between $\mathrm{Nu} \_$predicted and $\mathrm{Nu} \_$experimental for straight tube.

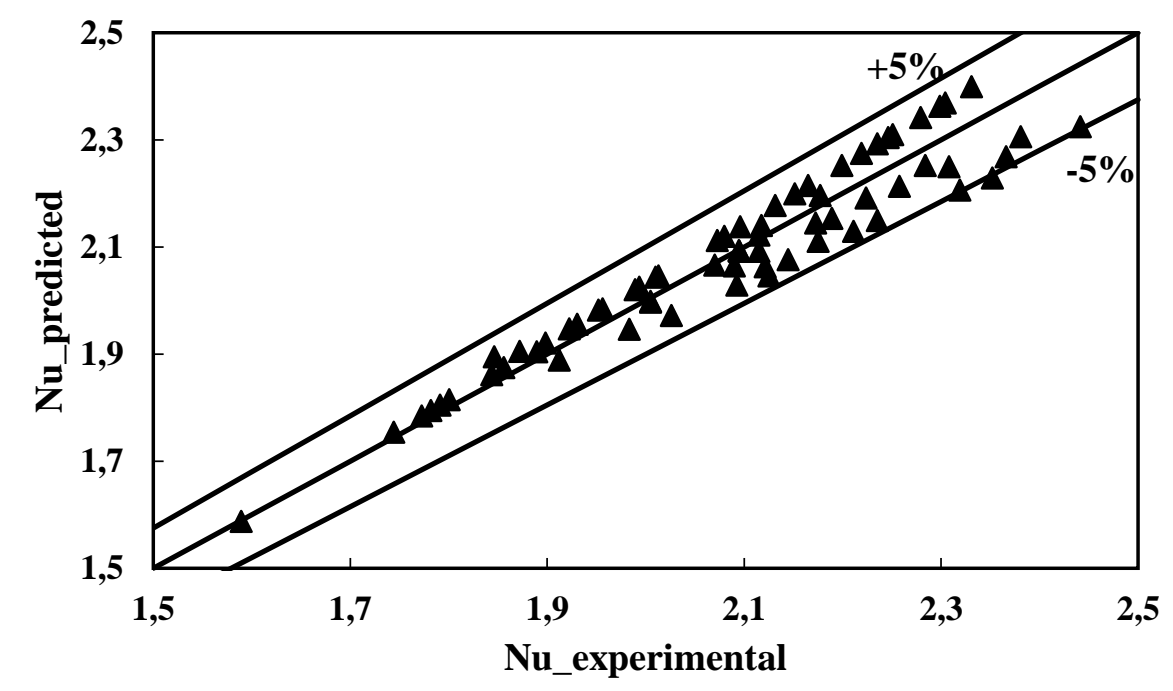

Figure 19. Parity plot between $\mathrm{Nu} \_$predicted and $\mathrm{Nu}$ _experimental for helical coils. 


\section{CONCLUSION}

Forced convective heat transfer studies for laminar flow of $\mathrm{MgO} / \mathrm{PG}-\mathrm{W}$ nanofluid for volume concentrations of $0.66 \%$ and $0.3 \%$ in straight tube and helical coils were conducted.

- Thermal conductivity and viscosity of MgO/PG-W based nanofluids were experimentally determined in the required temperature range of 20 to $35^{\circ} \mathrm{C}$.

- Experimental results showed the maximum thermal conductivity enhancement of $7.5 \%$ and $10.5 \%$ for a volume conc. of $0.3 \%$ and $0.66 \%$ respectively of $\mathrm{MgO} / \mathrm{PG}-\mathrm{W}$ at a temperature of $33^{\circ} \mathrm{C}$.

- In straight tubes, convective heat transfer coefficient of $0.66 \mathrm{vol} . \% \mathrm{MgO} / \mathrm{PG}-\mathrm{W}$ nanofluid was found to be $24 \%$ higher as compared to that of PG/W base fluid.

- Significant enhancement of $83.1 \%$ and $95.94 \%$ in rate of heat transfer, $Q$, and $30.24 \%$ and $70.84 \%$ in heat transfer coefficient, $\mathrm{h}$ in respect of the base fluid is observed with increase in concentration of $\mathrm{MgO}$ from $0.3 \%$ to $0.66 \%$ in the base fluid respectively at a Reynolds number of 1840

- The increase in heat transfer characteristics of MgO/PG-W nanofluid could be due to:

(i) increase in, the surface area per unit volume provided by the nanoparticles, the heat capacity and the apparent thermal conductivity of the fluid.

(ii) local turbulence caused by random interaction and collision among nanoparticles resulting in flattening of local temperature profile within the nanofluid.

- In helical coils, the effect of curvature ratio on Nusselt number was studied and experimental results showed that the Nusselt number increased with increase in curvature ratio. For a curvature ratio of 0.0533 and 0.66 vol. \% nanofluid, maximum enhancement in heat transfer coefficient was $17.5 \%$ whereas for a curvature ratio of 0.0727 , maximum enhancement was $23 \%$ for same volume concentration.

- A new correlation (equation (20)) has been proposed to estimate the Nusselt number for laminar flow of $\mathrm{MgO}$ based nanofluids through straight tubes as a function of particle volume fraction for $0 \leq \phi \leq 0.66 \%$.

- The coil Nusselt number was found to be a function of geometrical parameters of helical coil. A new correlation (equation (21)) to estimate the coil Nusselt number for laminar flow of base fluid as well as $\mathrm{MgO}$ nanofluids has been proposed for $0 \leq \phi \leq 0.66 \%$ and $100 \leq \mathrm{De} \leq 1000$.

- Effect of further increase in concentration of $\mathrm{MgO}$ nanoparticles thereby affecting stability, heat transfer coefficient and Nusselt number under turbulent flow conditions, both in straight tubes and helical coils can be considered for further studies.

- Effect of coil geometry, viz. curvature ratio, coil diameter and pitch on convective heat transfer coefficient under turbulent flow conditions need to be studied.

\section{ACKNOWLEDGEMENT}

One of the authors (Parminder Singh) acknowledges the financial support provided by DST-PURSE-II (Ref. no. 79-81/RPC) as fellowship to carry out his research work. The authors are also thankful to DST-PURSE-II and TEQIP-II, Dr. SSBUICET, PU for providing grants for purchase of chemicals.

\section{DISCLOSURE STATEMENT}

No potential conflict of interest was reported by the authors.

\section{NOMENCLATURE}

$\mathrm{D}$ outside diameter of coil support, $\mathrm{m}$

$\mathrm{D}_{\mathrm{c}}$ coil diameter, $\mathrm{m}$

$\mathrm{d}_{\mathrm{i}} \quad$ inside diameter of the tube, $\mathrm{m}$

$\mathrm{d}_{\mathrm{o}} \quad$ tube outer diameter, $\mathrm{m}$

$\mathrm{L}_{\text {coil }}$ coil length, $\mathrm{m}$

$\mathrm{L}$ length of a test section, $\mathrm{m}$

$\mathrm{N}$ number of turns

$\mathrm{p}$ coil pitch, $\mathrm{m}$

$k$ thermal conductivity, (W/m.K)

$v$ fluid velocity, $(\mathrm{m} / \mathrm{s})$

$\mathrm{C}_{\mathrm{p}}$ specific heat capacity, $\left(\mathrm{J} / \mathrm{kg}^{\circ} \mathrm{C}\right)$ 
Re Reynolds number

Pr Prandtl number

$\mathrm{Nu}$ Nusselt number

Pe Peclet number $=$ Re.Pe

He Helical number

De Dean number $=R e \sqrt{\frac{d_{i}}{D_{c}}}$

$Q$ Heat transfer rate, $\mathrm{W}$

$m$ mass flow rate, $\mathrm{kg} / \mathrm{s}$

$C$ specific heat, $\mathrm{J} / \mathrm{kg} .{ }^{\circ} \mathrm{C}$

$T$ temperature of fluid, ${ }^{\circ} \mathrm{C}$

$U$ overall heat transfer coefficient, $\left(\mathrm{W} / \mathrm{m}^{2} . \mathrm{K}\right)$

$h$ convective heat transfer coefficient, $\left(\mathrm{W} / \mathrm{m}^{2} . \mathrm{K}\right)$

A surface area, $\mathrm{m}^{2}$

C.R curvature ratio $=\mathrm{D}_{\mathrm{c}} / \mathrm{d}_{\mathrm{i}}$

P.R pitch ratio $=\mathrm{p} / \mathrm{d}_{\mathrm{i}}$

$\Phi$ nanoparticle volume fraction

$\mu$ dynamic viscosity (Pa.s)

$\rho$ density $\left(\mathrm{kg} / \mathrm{m}^{3}\right)$

\section{Subscripts}

c cold fluid

h hot fluid

o outside

i inside

p nanoparticle

bf base fluid

nf nanofluid

PG/W mixture of (60:40, by wt. \% Propylene glycol and water)

SL straight tube, laminar condition

ST straight tube

LMTD log mean temperature difference

exp experimental

w tube wall conditions

\section{REFERENCES}

[1]Nasiri, M., Etemad, S. G., \& Bagheri, R. (2011). Experimental heat transfer of nanofluid through an annular duct. International Communications in Heat and Mass Transfer, 38(7), 958-963. [2]McQuiston, F. C., \& Parker, J. D. (1982). Heating, ventilating, and air conditioning: analysis and design. [3]Choi, S. U. S., Singer, D. A., Wang, H. P. (1995) Developments and Applications of Non-Newtonian Flows. [4]Gupta, R., Singh, P., \& Wanchoo, R. K. (2013). Heat Transfer Characteristics of Nano-Fluids. Materials Science Forum, 757 ,

175-195.

[5]Saidur, R., Leong, K. Y., \& Mohammad, H. A. (2011). A review on applications and challenges of nanofluids. Renewable and Sustainable Energy Reviews, 15(3), $1646-1668$. [6]Pak, B. C., \& Cho, Y. I. (1998). Hydrodynamic and heat transfer study of dispersed fluids with submicron metallic oxide particles. Experimental Heat Transfer, 11(2), 151-170. [7]Wen, D., \& Ding, Y. (2004). Experimental investigation into convective heat transfer of nanofluids at the entrance region under laminar flow conditions. International Journal of Heat and Mass Transfer, 47(24), 51815188.

[8]Heyhat, M. M., Kowsary, F., Rashidi, A. M., Momenpour, M. H., \& Amrollahi, A. (2013). Experimental investigation of laminar convective heat transfer and pressure drop of water-based $\mathrm{Al} 2 \mathrm{O} 3$ nanofluids in fully developed flow regime. Experimental Thermal and Fluid Science, 44, $483-489$. [9]Hemmat Esfe, M., Saedodin, S., \& Mahmoodi, M. (2014). Experimental studies on the convective heat transfer 
performance and thermophysical properties of $\mathrm{MgO}$-water nanofluid under turbulent flow. Experimental Thermal $\begin{array}{llrr}\text { and } & \text { Fluid } & \text { Science, } & \text { 68-78. }\end{array}$ [10]Xie, H., Li, Y., \& Yu, W. (2010). Intriguingly high convective heat transfer enhancement of nanofluid coolants in laminar flows. Physics Letters, Section A: General, Atomic and Solid State Physics, 374(25), $2566-2568$. [11]Xuan, Y., \& Li, Q. (2003). Investigation on Convective Heat Transfer and Flow Features of Nanofluids. $\begin{array}{llll}\text { Journal } & \text { Heat } & \text { Transfer, } & 151 .\end{array}$ [12]Li, Q., \& Xuan, Y. M. (2004). Flow and Heant Transfer Performances of Nanofluids Inside Small Hydraulic Diameter Flat Tube. Journal of Engineering Thermophysics, 25(2), 305-307. [13]Lai, W. Y., Phelan, P. E., Vinod, S., \& Prasher, R. (2008). Convective heat transfer for water-based alumina nanofluids in a single 1.02-mm tube. In 2008 11th IEEE Intersociety Conference on Thermal and Thermomechanical Phenomena in Electronic Systems, I-THERM (pp. 970-978). [14]Jung, J. Y., Oh, H. S., \& Kwak, H. Y. (2009). Forced convective heat transfer of nanofluids in microchannels. International Journal of Heat and Mass Transfer, 52(1-2), 466-472. [15]Zeinali Heris, S., Nasr Esfahany, M., \& Etemad, S. G. (2007). Experimental investigation of convective heat transfer of Al2O3/water nanofluid in circular tube. International Journal of Heat and Fluid Flow, 28(2), $203-210$. [16]Anoop, K. B., Sundararajan, T., \& Das, S. K. (2009). Effect of particle size on the convective heat transfer in nanofluid in the developing region. International Journal of Heat and Mass Transfer, 52(9-10), 2189-2195.

[17]Rea, U., McKrell, T., Hu, L. wen, \& Buongiorno, J. (2009). Laminar convective heat transfer and viscous pressure loss of alumina-water and zirconia-water nanofluids. International Journal of Heat and Mass Transfer, 52(7-8),

2042-2048.

[18]Xuan, Y., Li, Q., \& Hu, W. (2003). Aggregation structure and thermal conductivity of nanofluids. AIChE Journal, $\quad 49(4)$ 1038-1043. [19]Maïga, S. E. B., Nguyen, C. T., Galanis, N., \& Roy, G. (2004). Heat transfer behaviours of nanofluids in a uniformly heated tube. In Superlattices and Microstructures (Vol. 35, pp. 543-557). [20]Duangthongsuk, W., \& Wongwises, S. (2010). An experimental study on the heat transfer performance and pressure drop of $\mathrm{TiO} 2$-water nanofluids flowing under a turbulent flow regime. International Journal of Heat and Mass Transfer, $\quad$ 53(1-3), 334-344. [21]Vajjha, R. S., Das, D. K., \& Kulkarni, D. P. (2010). Development of new correlations for convective heat transfer and friction factor in turbulent regime for nanofluids. International Journal of Heat and Mass Transfer, 53(21-22), 4607-4618.

[22]Sajadi, A. R., \& Kazemi, M. H. (2011). Investigation of turbulent convective heat transfer and pressure drop of $\mathrm{TiO}$ 2/water nanofluid in circular tube. International Communications in Heat and Mass Transfer, 38(10), 14741478 .

[23]Asirvatham, L. G., Raja, B., Lal, D. M., \& Wongwises, S. (2011). Convective heat transfer of nanofluids with correlations. Particuology, 9(6),

626-631.

[24]Kubair, V., \& Kuloor, N. R. (1966). Heat transfer to Newtonian fluids in coiled pipes in laminar flow. International Journal of Heat and Mass Transfer, 9(1), 63-75. [25]Schmidt, E. F. (1967). Heat transfer and pressure loss in spiral tubes. Chemie Ingenieur Technik, 39(13), 781. [26]Seban, R. A., \& McLaughlin, E. F. (1963). Heat transfer in tube coils with laminar and turbulent flow. International Journal of Heat and Mass Transfer, 6(5), 387-395. [27]Dravid, A. N., Smith, K. A., Merrill, E. W., \& Brian, P. L. T. (1971). Effect of secondary fluid motion on laminar flow heat transfer in helically coiled tubes. AIChE Journal, 17(5), 1114-1122. [28]Janssen, L. A. M., \& Hoogendoorn, C. J. (1978). Laminar convective heat transfer in helical coiled tubes. International Journal of Heat and Mass Transfer, 21(9), 1197-1206. [29]Manlapaz, R. L., \& Churchill, S. W. (1981). Fully developed laminar convection from a helical coil. Chemical Engineering Communications, 9(1-6), 185-200. [30]Cioncolini, A., \& Santini, L. (2006). An experimental investigation regarding the laminar to turbulent flow transition in helically coiled pipes. Experimental Thermal and Fluid Science, 30(4), 367-380. [31]Jamshidi, N., Farhadi, M., Sedighi, K., \& Ganji, D. D. (2012). Optimization of design parameters for nanofluids flowing inside helical coils. International Communications in Heat and Mass Transfer, 39(2), 311-317. [32]Akhavan-Behabadi, M. A., Pakdaman, M. F., \& Ghazvini, M. (2012). Experimental investigation on the convective heat transfer of nanofluid flow inside vertical helically coiled tubes under uniform wall temperature condition. International Communications in Heat and Mass Transfer, 39(4), 556-564. 
[33]Hashemi, S. M., \& Akhavan-Behabadi, M. A. (2012). An empirical study on heat transfer and pressure drop characteristics of $\mathrm{CuO}$-base oil nanofluid flow in a horizontal helically coiled tube under constant heat flux. International Communications in Heat and Mass Transfer, 39(1), $144-151$. [34]Mukesh Kumar, P., Kumar, J., Suresh, S. (2012) Heat transfer and friction factor studies in helically coiled tube using Al2O3/water Nanofluid. European Journal of Scientific Research, 82, 161 - 172. [35]Hall, B. D., Zanchet, D., \& Ugarte, D. (2000). Estimating nanoparticle size from diffraction measurements. Journal of Applied $\quad$ Crystallography, 33(6), 1335-1341. [36]Davarnejad, R., \& Jamshidzadeh, M. (2015). CFD modeling of heat transfer performance of MgO-water nanofluid under turbulent flow. Engineering Science and Technology, an International Journal, 18(4), 536-542. [37]Parsons, R., Kuehn, T. H., Couvillion, R. J., Coleman, J. W., Suryanarayana, N., \& Ayub, Z. (2005). ASHRAE Handbook-Fundamentals. ASHRAE

Handbook-Fundamentals.

[38]Sharma, P., Singh, P., Gupta, R., \& Wanchoo, R. K. (2017). Hydrodynamic Studies on MgO Nanofluid Flowing Through Straight Tubes and Coils. Journal of Nanofluids, 6(3), 558-566. [39]Sieder, E. N., \& Tate, G. E. (1936). Heat Transfer and Pressure Drop of Liquids in Tubes. Industrial and Engineering Chemistry, 28(12), 1429-1435. [40]Syam Sundar, L., \& Sharma, K. V. (2011). Laminar convective heat transfer and friction factor of AL2O3 nanofluid in circular tube fitted with twisted tape inserts. International Journal of Automotive and Mechanical Engineering, 3(1), 265-278. 